\title{
Futures studies serving the development of future orientation in Hungary \\ Short title: Futures studies in Hungary
}

\author{
Erzsébet Nováky - Éva Hideg - Klára Szita Tóthné
}

- folyóiratcikk, 2017 -

\begin{abstract}
The paper presents a chronological overview and assessment of futures studies in Hungary. Futures in Hungary can be divided into two well discernible phases: the first one from the inception to the political turn characterized by a vertical and horizontal construction of the discipline, the second one characterized by its theoretical and methodological renewal and practical implementation. As an interdisciplinary study, Hungarian futures had been integrated into international futures studies in both phases. The paper, besides the overview of the theoretical and methodological results, also presents the current state of the education of futures studies. It is shed a light on the complex future images and the efforts of Hungarian futures studies in the service of practice. Finally, it considers the tasks that lie ahead of the futures studies in the coming years.
\end{abstract}

Keywords: futures studies in Hungary, futurology-futures, complex future images, education, future orientation, international cooperation.

\section{The beginnings of futures studies in Hungary}

Institutional futures studies have a 48-year history in Hungary. The inception of futures can be dated to the same year of the foundation of the Club of Rome, in September 1968, when the head of the Department of National Economic Planning of the Karl Marx University of Economic Sciences (KMUES) (the legal predecessor of the present-day Corvinus University of Budapest (CUB)), university professor Géza Kovács announced a research seminar on futurology-futures studies for students.

The nascent futures studies did not meet the approval of either state or educational institutions. The system of socialist central planning did not allow for futures studies (futurology and prognostics) stemming from the bourgeois (market) environment. Dominant political opinion preconized that future goals, orientation and paths can be appropriately assigned in the framework of the socialist central planning, therefore there is no need for this bourgeois discipline (they even questioned its being a science). This ideological factor had long been a theoretical obstacle to the reception of futures studies. The expansion of futures studies, predominantly in education and in the solution of scientific problems requiring future perspectives, has been facilitated by the transformation of the international environment, the East-West political détente, the appearance of global problems, the decreasing efficiency of the socialist central planning and the adoption of a new economic mechanism, and finally the rising prognostics in the Soviet Union. 


\section{Two phases of the Hungarian futures studies}

The phase from the beginnings up to the political turn (1968-1990) was characterized by vertical and horizontal construction of the discipline. The research and education of various aspects of the future was introduced at practically all the bigger universities in the country. The base for Hungarian futures studies, the Futurology Group was initiated by professor Kovács of the KMUES, research targeting theoretical and methodological issues, focusing on macro scale long term societal, economic and regional problems.

The philosophical and systemic issues of futures studies were dealt with at the Department of Philosophy of the Budapest University of Technology (BUT). Generic and methodological issues as well as medical issues pertaining to futures studies became the specialty of the Semmelweis Medical School. Short term prognosis and cycles were researched at the Pecs University. Futures studies was incorporated into the research of global economic phenomena at the Global Economic Research Institute of the Hungarian Academy of Sciences (HAS). A process of definition and systematization of concepts in futures studies was launched at the Scientific Management Institute of the HAS.

It must be recognized that in the few years following the inception of the field, the institutional organization of Hungarian futures studies (and its national and international significance) had been the target of regular attacks questioning its viability as a scientific field. Having this in mind, we greatly appreciate the fact that the HAS recognized Hungarian futures studies as an autonomous field of science at a relatively early stage, by establishing the Committee on Future Research under its Section of Economics and Law, presided by Géza Kovács. After nearly 10 years of existence of the field, this was seen as an obvious manifestation of recognition by the national scientific public. This committee, establishing itself as the interdisciplinary forum of national futurists came to be the scientific partner of the Hungarian Planning Institute, focused on long term planning, supervised the scientific quality of the national conference on futures studies and initiated bi- and multilateral international cooperation. Both our participation in the Prognostics Workgroup of the Comecon and the professional connection with the World Futures Studies Federation (WFSF) proved to be decisive in the process. The international recognition of the research results of the first years had been assured by foreign language publications by Hungarian authors and personal contacts by WFSF members. A further sign of recognition was when in 1987, Hungary was given the opportunity to organize and host - under the presidency of Erzsébet Gidai - the international conference entitled 'Technology of Future and Its Social Implications' (Nováky-Schmidt eds.1988) and the 11th WFSF world conference entitled 'Linking Present Decisions to Long-Range Visions‘ (Mannermaa ed.1992).

The second phase - starting from the political turn up to today (1990-2015) had been characterized by the theoretical and methodological renewal and practical implementation of futures studies in Hungary. The quest for adequate responses addressing international and national challenges created a novel situation for futures studies. On the national side, the challenges included tackling unstable existential situation, the escalation of uncertainty, the expansion and reinforcement of the role of the individual in the shaping of future, value system 
shifts and futures studies addressed these issues by innovative research theory and methodology. There was a growth in the significance of the practice-oriented futures research - including company/enterprise strategy development and planning. At the same time, the subject of futures studies came to be a topic of discussion in university movie clubs, in the media and on the internet - all contributing to the diversity of discussion fora. Concomitantly, an increased interest in the forecasting could be felt.

In the meanwhile, the cooperation with WFSF was intensified: in the period between 19992005 four international summer university programs (Budapest Futures Course) were organized and hosted by a team headed by Erzsébet Nováky committee president and another WFSF world conference hosted in 2005. At this time, Hungary was the unique country to have held WFSF world conferences on two occasions. Communications of the $19^{\text {th }}$ WFSF world conference entitled 'Futures Generation for Future Generations' are published at the website of the WFSF (Bakos-Gáspár eds. 2005, www.wfsf.org).

In addition to the above results, in 2001, Hungarian futurists managed to edit and publish a compilation of the history of futures studies, views on the futures studies and future by leading futurists of the ex-socialist countries (Nováky-Ramba Varga-Kalas Köszegi eds. 2001).

Participation in the following international research cooperation can be seen as a token of recognition of national futures studies: Prospective Technology Studies, Karlsruhe Institute for Technology, 2001-2011 (national lead researcher: Imre Hronszky, BUT), Strategies towards the Sustainable Household, 1998-2000 (national lead researcher: Klára Szita Tóthné, University of Szeged), Cost Action 22: Advancing Foresight Methodologies: Exploring New Ways to Explore the Future, 2004-2007 (national lead researcher: Éva Hideg, CUB), the AUGUR Project: Challenges for Europe in the World of 2030, Socio-economic sciences and the Humanities Theme 8, 2009-2010 (national participant: Erzsébet Nováky, CUB).

The Hungarian chapter of the Club of Rome (HuCoR) was led by László Kapolyi, member of the Hungarian Academy of Sciences, in the period between 2008-2015. From 2004 to 2010, he also provided financial support for the so-called 'Forest Future School' organized annually in Kétbodony. This program had become an informal forum of discussion of current and interesting issues for educators and teaching assistants of futures studies, teaching aids under the umbrella of the Futures Studies Department of CUB, professors and students of other universities.

Hungary Node was established in December 2013, when we officially adhered to the Millennium Project currently operational in 60 countries. We produced the State of Futures Index (SOFI) for Hungary and for the V4 (Visegrad 4) countries (Bartha and others 2015).

\section{Advances in the theoretical and methodological research}

Research results of the initial period clarified the connection between futures studies and planning in the framework of socialism and defined it as an outer circle in planning (Kovacs, 1970). This was based on the belief that futures studies, by exploring options, is able to offer a 
wide range of alternatives for the planning activity comprising of elements of decision. Conceptual issues were clarified as well (Fodor-Schmidt-Haraszthy 1976). Amongst the issues pertaining to methodology, special emphasis was laid on the cognition and determination of future, and the definition of the status of heuristics, quantification and alternativity within futures studies. Heuristics was considered as a significant constituent in futures studies; quantification helped in the cognition and forecasting of poorly structured problems, alternative viewpoint reinforced the flexible interpretation of future options. Systematization of methods used in futures studies (Besenyei-Gidai-Nováky 1977) and the adaptation of the cross-impact method to national framework conditions (Nováky-Lóránt 1978) helped develop scientific discernment and brought practical availability of futures studies. The process was completed with the examination of reliability of forecasts (Besenyei-Gidai-Nováky 1982). Identification and connection of varied length cycles helped break systemic barriers imposed upon futures studies by the socialist regime (Sipos 1985; Hoós 1996).

Advances in the field of futures studies assisted long term planning, the elaboration of macro, sectoral- and regional concepts. Futures studies finally came to established in the system of science. In connection with the study of global models (Korán 1980), global problems occurring in Hungary as well as long term responses in reaction to the problems had been studied and this work is currently going on (Simai 1976, 2007a and 2014).

Societal, economic and political transformation in the 1990's demonstrated that the future is not a basically stable continuation of the past and the present. Former trends were broken, instability and uncertainty grew and new and unexpected events happened, leaving limited possibility for their anticipation. In response, national futures studies laid special emphasis on signals weakly discernible in the present, but significant and determinative in the future.

New types of responses were sought to address novel issues as a number of factors had changed: our attitude to future (by becoming more direct and multi-folded), the actors of futures studies (by the enlargement of the circle of those involved in futures studies), and the need to know the future became more acute (we wanted to know future in its dynamics, while concomitantly conserving past and present conventions and renewal). Thus, it became a requirement to transform and renew the entire futures studies' methodology had to be renewed. The essence of the renewal lies in the simultaneous interpretation of the process dynamics and changeability (including the option of breaking the stable trends and the significant societal effect of lesser changes) with the efforts of societal actors to have an impact on future, interpreting and seeking for the shaping forces of future.

We made it clear that in unstable conditions it is not possible to elaborate a single future alternative with high probability value (i.e. prediction), instead, it is possible to unfold a multitude of more or less equally probable versions of the future. The response provided by futures to instability was the methodological modeling of these transformations in the approach: the application of chaos theory in futures studies and the exploration of evolutionary development as pertaining to futures. In the light of the interpretation of chaos theory, the chaotic behavior of several major national macro indicators were investigated (Nováky-Hideg- 
Gáspárné 1997; Nováky-Orosz 2015). Evolutionary model analyses - in conjunction with postmodern approach - provided novel findings in the explorable future patterns (Hideg ed. 1998; Hideg ed. 2001).

Agent models, statistical tools of research in business cycles and market research, the method of neural networks were studied and implemented in case studies. Related areas of futures studies and ICT were equally studied, with special focus on data mining known in economic informatics as applied to futures studies. The connection between economics and futures studies was reinforced. The examination of the relationship between forecasting and foresight is the product of this period. The first foresight-type forecasts were elaborated in the areas of education and regional issues (Hideg ed. 1995; Hideg-Nováky 1998a; Nováky 2003; Bartus and others 2007). Our education-specific forecast is among the first ones in Europe (HidegNováky-Kristóf 2013).

The definition of future orientation (Nováky-Hideg-Kappéter 1994), in function of factors defining or enhancing individuals' positive attitude to future was accepted internationally. Investigation into future orientation provided a bridge between the so-called consequencefutures emanating from the past and distant future images that can be interpreted in a normative way, opening the way to a series of empirical studies (Hideg-Nováky 1998b; Hideg-Nováky 2010).

The evolving role of lay individuals shed light on the importance of participatory futures studies, closely related to the phenomenon of action orientation (Nováky 2006). Lay individuals as well as communities had increasingly expressed their need to alter future in a variety of spheres of activity. Summated collective responsibility (or irresponsibility) of the individuals and community actions can significantly shape future.

The unstable nature of the environment resulted in the reinforcement of perspective thinking, application of simultaneous multilateral complexity (inclusive of consideration for weak signals), participativity (inclusion of laymen and stakeholders in the outline of future alternatives), the importance of impact studies, responsible future oriented thinking and alternative approach. The new methodology of futures studies does not only serve to understand unstable situations but it helps bring the outline and planning of future closer to the stakeholders and non-experts thus enabling the elaboration of future alternatives deemed acceptable by both the wider community and feasible by the scientists in a given space. This approach places more emphasis on creativity and interactivity (Hideg ed. 2009).

Like in other fields, the pattern of detecting diverse trends had been palpable in futures as well (Hideg 2002), and characteristic paradigms such as evolutionary and critical paradigms in futures studies next to positivist futures research followed by the subsequent integral futures paradigms, indicating the potential for heterogeneous approaches and their synthesis came to existence (Hideg 2013; Hideg 2015). 


\section{Complex images of the future}

Futures studies in Hungary is characterized by the regular elaboration of a complex national image of the future.

The first national image of the future, based on foresight up to 2000 was published at the end of the 1960's (Kovács 1970). The central facet of this future image adopting the top $\rightarrow$ down approach was the combination of indicators such as GDP, the change in the employment patterns and the increasing role of education and research. The second future image adopting the bottom $\rightarrow$ up approach investigated the change in the human needs (Kovács 1979). Both of the future images stipulated a fundamental change. The first one construed the requirement of a considerable increase in the capital intensity of production, the efficiency of tangible assets and capital formation, as well as a significant transformation of the country's economic structure up to the turn of the millennium. The findings of the second investigation stipulated that the increasing demand, up to 2020, justified by scientific research, could be solely met in a research-intensive production and service sector instead of relying on the industrial society.

The third and fourth complex national future images were featured in the renewed futures studies framework. A top $\rightarrow$ down and bottom $\rightarrow$ up complex approach was used in the third future image (Nováky ed. 2001). This approach also constituted the framework for the comparison of future alternatives based on foreseeable economic and political conditions, and community requirements. We were not seeking for the optimum future alternative, but for the acceptable ones as stipulated by the given conditions and expectations. The criterion for acceptability was the availability of space for the community and its members, that is, the formation of diverse paths (in the case of individuals, life- and career paths) and the adoption of these paths. Based on the alternatives and nodes, eight future images were elaborated. From the eight alternatives, there was only one acceptable for the community without reserve: the one factoring in regional integration, application of economic policy securing the sustainable protection of the country's interest and balanced growth within the EU. In this version of the future alternative new societal values can be realized, new individual target values and instrumental values (such as credibility, responsibility, braveness, reason and helpfulness) can be developed. The future alternatives were envisioned with respect to possibilities and expectations. Four characteristic complex future alternatives came to be distinguished, representing renewal and invariance, stability, and instability.

The fourth complex future image (Nováky ed. 2010; Nováky-Várnagy 2013), commissioned by the president of the HAS in 2007 representing Hungary in 2025 was formulated in collaboration with the Committee on Future Research of its Section IX, drawing on expert forecasts from various fields of science and non-expert opinions. In the process, three theoretical principles of futures studies were applied: complexity, participativity and alternativity. At one pole of the past-present-future complex system stood the expert concerns and expectations while at the other pole were the non-expert future expectations embodied in fears and hopes. These two spheres combined constitute the space of action where the future of the country can be shaped by decisions inducing change and transformation as well as 
facilitating adaptability. Future expectations pertaining to the future exert a transformative and pull effect on our present. Consequently, not all expert hopes can be realized, only those which are supported by communities articulating future expectations by their individual decisions and acts. By the same token, non-expert fears will solely come true in case communities, not recognizing dangers portrayed, will avoid assumption of the solution. This bidirectional approach is embodied in alternativity. In the "Hungary 2025" study, there were four future alternatives. Research findings stipulated that the foundations of the socio-economic conditions of Hungary in 2025 are laid in the present. There are chances for a favorable future alternative as for a more difficult situation for the next generation caused by our acts.

\section{Education of futures studies in Hungary}

The inception of the field at the end of the 1960's saw the concomitant launch of its integration into national higher education. The launch was mainly instigated by the presence of a significant number of beginning futurists in higher education. Maintaining a close cooperation between education and research, the research and teaching fellows and their laboratories headed the establishment and the subsequent development and propagation of futures education.

In this period, courses in futures education were launched at four universities: three in Budapest in Pecs. At the KMUE, a course entitled Futurology mapping the issues of the future, and another course entitled Long term futures studies were developed and launched under the supervision of Géza Kovács. Imre Korán and Lajos Besenyei developed and taught courses on Economic Forecasting and Business Forecasting. At the BUT, Judit Fodor, Éva Gabor and Attiláné Tóth launched a special seminar on the philosophical issues of futures studies. At the Semmelweis Medical School, the education of issues related to the theoretical, methodological and medical aspects of futures studies was organized and launched by Erzsébet Gidai (Gidai 1974; Gidai 1990). At the Janus Pannonius University (Pécs) Bela Sipos launched a course on Business Prognostics.

The political turnover exerted an acceleration in the transformation of futures education. Around the turnover years, new provincial universities launched courses - the University of Miskolc (UM), the University of Western Hungary (UWH), the Szent István University (SZIU), under the guidance of Lajos Besenyei, Erzsébet Nováky, János Czabán, János Hoós, Erzsébet Gidai, and László Pitlik.

In the meanwhile, the KMUE became Budapest University of Economics (BUE) and there was an increase in the number of courses of futures and in the number of students coming from a larger variety of specializations. For instance, futures education was made compulsory for education students. New courses such as Futures, Socio-economic Forecasts, Education and Future, Societal Forecasts, Business Cycles Research, Economic Forecasting were developed and launched by Erzsébet Nováky, Éva Hideg, and János Hoós. The curricula of these courses drew upon the forecast activities of the futurists. At the BUE, an autonomous Futures Studies Department was created under the auspices of Erzsébet Nováky. This department, other than offering special futurist courses for business education, became the unique institutionalized education center in the country teaching the discipline of futures in its complexity at a higher 
education level. The first Futures textbook was compiled for the inception of the department (Nováky ed. 1992).

In the meanwhile, at the BUT, the course entitled Forecasts, future images was offered at the Department of Innovation Management and History of Technology in between 2000-2007. Attiláné Tóth taught this course at the UWH in between 2000-2006 and Endre Kiss taught a course entitled Globalization amalgamating philosophy and futures in a peculiar way. He has been teaching the same course at several higher education institutions with great success since the mid-2000's.

The adoption of the Bologna education system required the reorganization of national futures education. Consequently, there was a considerable cut in the number of courses offered at higher education institutions. At the Corvinus University of Budapest (CUB), futures were offered in the elective course entitled Futures Studies for BSc students. At the MSc level, the elective courses entitled Futures Studies and Alternative Future Images are offered by Erzsébet Nováky and Éva Hideg. The Enterprise development MSc curriculum came to be complemented by a new obligatory course, entitled Societal and Economic Forecasting - a special product of the Bologna process. This futures course, in its practice orientation has proven to fully accomplish its purpose of vocational training. It was developed and has been taught by Hideg and Nováky since 2008 (Hideg since September 2013).

At the BUT futures are solely offered in a one-semester BSc elective course entitled Studies and curiosities. This course is taught by Zoltan Galántai at the Department of Finances. At the Wekerle Sándor Business School, the elective Futures course has been taught by Attiláné Tóth since 2008. Gábor Koncz has been incorporating futures and cultural forecast in his courses at the Edutus Business School and its legal predecessors for ten years as well as at the Sárospatak Academy of Theology reformed community studies BA courses for four years.

The education of futures in the country has been complemented by the catering for the course material. Textbooks, notes, compendia and other course material aligned with the education objectives of individual institutions have been developed. Course material has been catered by the Futures Case Studies and Futures Theories note series (Hideg ed. since 1996 and 1998), presenting and discussing Hungarian futures case studies as well as modern issues in the theory and methodology of futures.

The international cooperation of national futures studies became more dynamic around the turn of the millennium. The Futures Department at the CUB organized the earlier mentioned Budapest Futures Course sponsored by WFSF UNESCO on four occasions in between 19992005. The manifest success of the course helped the Department become an internationally recognized educational workshop.

Futures education has become part of the newly launched $\mathrm{PhD}$ education programs at the CUB. In the Doctoral School of Business Informatics, a sub-program of Futures Studies was launched in 2009 under the auspices of Erzsébet Nováky. 
Education of futures in Hungary was accomplished in the first decade of the 2000's with its integration in the $\mathrm{PhD}$ and international education. However, this process coincided with the permeation of the effects of the great financial crisis in the country when the economic austerity measures hit higher education. This resulted in a significant drop in the number of futurist educators in $\mathrm{PhD}$ and international programs. Even in institutions with sustained futures education, the rejuvenation of futurist educators stagnated.

The positive assessment of the Bologna process is owing to the success of the Futures Department of the CUB in maintaining its leading role amongst the educational institutions in Hungary. On the negative side however, it is apparent that the futures has not become an autonomous profession and the supply of futures professionals has not been institutionalized.

While the first phase of futures education was centered on the definition of futures field, its position in the system of sciences, and the query into conceptual-methodological aspects, the subsequent years of emergence and massive expansion witnessed the transfer of focus on the explanation of individual prognoses and foresights, aligned with the specialization of students. As the 'use and implement principle', an educational objective in the Bologna process, has been gaining terrain in the futures education, students have become more active, contributing to the increasingly interactive character of the course. The use of internet in education and interaction with course students has been incremental.

With the accession of Hungary to the European Union, planning and foresight/forecast have become important practical fields. Unfortunately no BSc or MSc specialization has been created to meet the requirement for new experts.

\section{Futures studies in the service of practice}

Right from the inception, we have been striving to produce forecast by the rigorous implementation of the principles and methodology of scientific futures supporting sectorial and regional planning. The following topics are especially worth mentioning: the prognosis of the development of transportation, the evolution of construction industry leading up to the turn of the millennium, the information technology at crossroads, the future of biology, the global food security crisis, the production curves - business prognoses, the assessment of agrarian ecology. The development of urban and regional planning was largely assisted by studies such as the impact of the scientific-technological revolution on urban planning, the spatial redistribution of population, the transformation of human environment, the factors impacting socio-economic spatial structure and their evolution, the characteristics and evolution of the framework conditions of long term big spatial management and the investigation of correlation between European and national urban axes.

Salient studies on societal issues included the future of human beings as bio-psycho-social creatures and the options for resolving national housing conditions. The novelty of the investigation on evolution of criminality in Hungary up to the turn of the millennium lied in the use of a wider societal and economic context and the forecast applied all of the three groups of 
futures methodologies - mathematical-statistical methods, expert methods and modeling (Diczig and others 1982).

The study of climate change and its variability as well as the forecast of national environmental conditions were significant in the first phase of futures in Hungary. Recent and future relation between society, business and environment had been researched deploying significant mathematical battery in an interdisciplinary research team and in a module mode. These studies allowed for the forecast of the environmental conditions first in a given micro-region then in the whole of Hungary (Nováky ed. 1991). It was proved that the only future alternative acceptable from societal, ecological and economic standpoint can be accomplished by a fundamental alteration of the economy-environment relation, followed by the formulation and application of a humane- and ecology centered aspect.

In the aforementioned second phase of the national futures, in between 1990-2007, prognoses and foresight case studies pertaining to the development of education and vocational training were also utilized in the elaboration of the development concepts of the same sector.

In this phase, practice-oriented prognoses served primarily as pillars for strategies, such as the Hungarian urban network development, various macro-concepts and regional and urban development plans (Ligeti ed. 2010). In the period between 2010-2012 we developed an interactive foresight method, implicating the participation of SME's and futurists, to shape the future of SME's (small and medium enterprises) in the region of Central Hungary (HidegNováky-Alács 2014). A website was developed to this effect: Future SME, Futures Me (http://futuresme.uni-corvinus.hu/?author=2.)

In this phase we concentrated also on the sustainability. The mitigation of environmental exposure can decrease by the green and circular economy, and industrial ecological solutions and the assessment of these in life cycle approaches serves the long-term sustainability (Tóthné 2013; Tóthné 2014).

\section{Crises, ways out and the shaping of new research fields}

The global financial crisis of the 2010's exerted a significant effect on futures in Hungary. On one hand, research opportunities became restricted as a consequence of the limitation of research funds (such as the National Scientific and Research Funds). On the other hand, universities had different levels of intensity in access to funds, allowing futures to be studied at a small number of universities. Divestment in higher education had a similar effect, resulting in a significant decrease in the number of futurist educators and the integration of the only autonomous national department of futures.

The way out of crisis is to maintain the continuity in the research by sustaining theoreticalmethodological issues in futures as important areas. Currently this endeavor implicates the development of integrated and interactive futures and its dissemination in the country. A grant allows us to investigate the corporate foresight situation in the Visegrád 4 countries and the improvement of corporate foresight practices with Éva Hideg and Judit Gaspar as national 
foresight experts. The website of the project is: http://www.visegradforesight.itee.radom.pl/index.php/en/).

The scientific profile of the Futures Studies sub-program of the Doctoral School of Business Informatics draws upon the investigation of conceptual and methodological issues of futures as well as the dissemination of the results in the national institutional practice. In Hungary, business seems to retain its role as the domain for further development of futures owing to the multilateral effect between the two. Business informatics - while tapping into solutions in information theory and practice - has to be greatly focused on typical characteristics of the business sphere and its employment requirements. This justified the relative autonomy of business informatics. The correlation between business informatics and futures can be investigated from the aspect of i) elaboration of business forecasts/foresights, and ii) the particular research topics in futures.

In the first case, business informatics signify the application of ICT in forecast/foresight methods, and the alternatives in the management of novel types of databases resulting from the extensive use of internet, as well as forecast options. This involves the improvement of ICT solutions currently deployed in various business forecast/foresight and in future search, allowing for the systematization of ICT-driven forecast methodology by assisting the exploration and assessment of the future by businesses and various level business executives and policy-makers and the deployment of the methodology in the strategy building of the selected futures. It is especially important that the construction ICT systems necessitates the observation of forecast/foresight aspects. For example, the latest literature on the so-called corporate foresight considers it a proven fact that no business unit of any size or aspect can avoid the management of future, especially with regard to implementation options of managing future in the ICT context. The study of this intertwined system and the elaboration business ICT implementations can be regarded as one of the specific fields of business informatics, which cannot be managed successfully without the understanding of futures methodology. It is also worth mentioning that the big data investigations driven by business ICT can enhance the reliability of forecast.

In the second case, the investigation pertained to the forecast/foresight research needs as instigated by the new and continually renewed ICT and culture. In this field one of the research topics in formation is the generation of a quasi-unlimited number of complex futures, the implementation of which in strategy building has not yet been resolved. Another topic is the inclusion of quasi unlimited number of internal and external business stakeholders, and the third, theoretical question discusses how ICT in business and in other areas will impact our thinking about the future and our rational strategy formulation.

\section{Summary - What should futures studies be in Hungary?}

Futures in Hungary - since its inception - has been characterized by a scientific aspect, demonstrated by the role it plays in the national academic life (the activity of the scientific committee and the organization of scientific conferences) and its integration into the higher education of the country. In comparison to the other ex-socialist countries, Hungary joined the mainstream of international futures at a relatively early stage and became a reliable partner of 
the WFSF.

Futures education found the most favorable soil in business education, a feature that is unique in Hungary as contrasted to other regions of the world. The curriculum of futures courses at the various universities has become largely diversified, serving the requirement of the host universities. In the case of training of economists and technical educators, futures education had been instrumental to assist their perspective thinking and future shaping aptitude for over 40 years. Unfortunately, in the current teacher education futures has lost its place in fields formerly covered, instead, what can be observed is that some specific futures aspects of a given field are integrated into its overall curriculum. This is currently happening in the environmental sciences, corporate strategies, marketing and ethical economics partially. We hold the view that while this is not really futures, the presence and discussion of certain issues of the future definitely help recognize the importance of discussing the future and the contribution of futures field to shaping the future.

Unlike in the surrounding countries, the transformation of the political system did not help an acceleration in the development of futures in Hungary. Futures remained confined in the world of science and education. In the world of business and media, futures is considered a curiosity, a field of science that provides a conceptual a methodological foundation for decision-making. While practice in Hungary slowly and gradually adopts modern ways and methods of discussing the future, there is an increasing requirement for the activity of future oriented and innovative entrepreneurs, businessmen, managers and citizens. National futures, while sustaining and developing its international role and recognition, must meet these discernible requirements.

It is extremely important to secure the future of futures field and maintain its place in the academic sphere. At present, besides the drive to strengthen its educational role, even the conservation of the autonomous status of the discipline within the framework of the Hungarian Academy of Sciences remains a challenge. While future-oriented thinking has been laudably spreading in other fields as well as in practical life, we think that the reason for this is that it theoretically easier to maintain, develop and implement the long term perspective of futures, synthetizing-integrating and adopting systemic thinking, in harmony with the other fields of future shaping. Therefore, the task and responsibility of futurists is the quest for new directions, answers to new challenges, options or conflicts in the development, the discernment of queries and the intensification of involvement of youth enabling the passing on of the relay. Today, the task formerly assigned by Simai (Simai 2007b: 1135) seems more justified than ever: 'Activate and intensify the communication between futures, politics, governments and civic organizations in order to duly assess historical analogies, enhance the quality of models and scenarios, and enable the clarification of concepts and the promotion of decision-making and action.'

\section{Bibliography}

Bakos, Péter, and Tamás Gáspár. (eds.) Futures Generation for Future Generations. 19th World Conference of the WFSF, August 21-24. 2005. Budapest: Futures Studies Department, Corvinus University of Budapest, 2005. WFSF website, www.budapestfutures.org 
Bartha, Zoltán and others. State of the Future Index - Visegrad Group Countries (V4 SOFI). Warsawa: Polish Society for Futures Studies, 2015.

Bartus, Zsolt and others. Proposal for the Establishment of a Regional Vocational Examination Center Network in Hungary. (in Hungarian) Budapest: National Institute of Vocational and Adult Education, 2007.

Besenyei, Lajos, Erzsébet Gidai, and Erzsébet Nováky. Practice of Futures Research and Forecasting. A Handbook of Methodology. (in Hungarian) Budapest: Közgazdasági és Jogi Könyvkiadó, 1977.

Besenyei Lajos, Erzsébet Gidai, and Erzsébet Nováky. Forecasting - Reliability - Reality. (in Hungarian) Budapest: Közgazdasági és Jogi Könyvkiadó, 1982.

Diczig, István and others. Forecasting of Crime Against the National Economy and Social Property for the Years 1978-1990. (in Hungarian). Budapest: BM Könyvkiadó, 1982.

Fodor, Judit, Ádám Schmidt, and Ágnes Haraszthy. (eds.) Futures Research Glossary. (in Hungarian) Budapest: Akadémiai Kiadó, 1976.

Gidai, Erzsébet. What is the Futures Research? (in Hungarian) Budapest: Kossuth Kiadó, 1974.

Gidai, Erzsébet. Future Alternatives. Possibilities of Socio-economic Forecasting. (in Hungarian) Budapest: Akadémiai Kiadó, 1990.

Hideg Éva. (ed.) Futures Case Studies. (in Hungarian) 1-28. Budapest: Jövőkutatás Tanszék Budapesti Közgazdaságtudományi Egyetem - Gazdaságföldrajz és Jövőkutatás Tanszék Budapesti Corvinus Egyetem, 1996-2015.

Hideg Éva. (ed.) Futures Theories. (in Hungarian) 1-21. Budapest: Jövőkutatás Tanszék Budapesti Közgazdaságtudományi Egyetem - Gazdaságföldrajz és Jövőkutatás Tanszék Budapesti Corvinus Egyetem, 1998-2015.

Hideg, Éva. (ed.) Crossroads of Vocational Training. (in Hungarian) Budapest: Munkaügyi Minisztérium, Budapesti Közgazdaságtudományi Egyetem, Honfoglalás Betéti Társaság, 1995.

Hideg, Éva. (ed.) Postmodern and Evolution in Futures Research. (in Hungarian) Budapest: Jövőkutatás Tanszék Budapesti Közgazdaságtudományi Egyetem, 1998.

Hideg, Éva, and Erzsébet Nováky. Vocational Training and the Future. (in Hungarian) Budapest: Aula Kiadó, 1998a.

Hideg, Éva, and Erzsébet Nováky. “Our Relationship to the Future.” (in Hungarian) Magyar Tudomány 159, no. 1 (1998b): 3-17.

Hideg, Éva. (ed.) Evolutionary Models in Futures Studies. (in Hungarian) Budapest: Aula Kiadó, 2001. 
Hideg, Éva. "Implication of Two New Paradigms for Futures Studies." Futures 34, no. 3-4. (2002): 283-294.

Hideg, Éva. (ed.) Futures Studies in the Interactive Society. Budapest: Futures Studies Department Corvinus University of Budapest, 2009.

Hideg, Éva, and Erzsébet Nováky. "Changing attitudes to the future in Hungary." Futures 42, no. 3 (2010): 230-236.

Hideg, Éva. "Integral Futures Based on Paradigm Approach.” Futures 45, no. 1 (2013): 6-15.

Hideg, Éva, Erzsébet Nováky, and Tamás Kristóf. "Hungarian Educational Foresight 'Vocational Training and Future'". In Participation and Interaction in Foresight. Dialogue, Dissemination and Visions, edited by Kristian Borch, Sandra Dingli, and Michael Sørgaard Jørgensen, 223-237. Northampton: Edward Elgar Publishing, 2013.

Hideg, Éva, Erzsébet Nováky, and Péter Alács. „Interactive Foresight on the Hungarian SMEs.” Foresight 16, no. 4 (2014): 344-359.

Hideg, Éva. Paradigms in Futures Field. Futures Theories 21. Budapest: Economic Geographic and Futures Studies Department, CUB, 2015. http//unipub.lib.uni-corvinus.hu/1900/

Hoós, János. Business Cycle Research. (in Hungarian) Budapest: Budapesti Közgazdaságtudományi Egyetem, 1996.

Korán, Imre. World Models. From the Club of Rome Report to the UN Initiative. (in Hungarian) Budapest: Közgazdasági és Jogi Könyvkiadó, 1980.

Kovács, Géza. Long-Range Perspectives and Planning. (in Hungarian) Budapest: Közgazdasági és Jogi Könyvkiadó, 1970.

Kovács, Géza. Futures Research and Social Planning. (in Hungarian) Budapest: Közgazdasági és Jogi Könyvkiadó, 1979.

Ligeti, István. (ed.) Futures Images and Strategies. (in Hungarian) Budapest: ECOSTAT Gazdaság- és Társadalomkutató Intézet, 2010.

Mannermaa, Mika. (ed.) Linking Present Decisions to Long-Range Visions. XI. World Conference of the WFSF, May 27-31. 1990. Budapest, Selection of papers. Budapest: Committee on Future Research HAS, 1992.

Nováky, Erzsébet and Károly Lóránt. "Method for the Analysis of Interrelationships Between Mutually Connected Events A Cross-Impact Method." Technological Forecasting and Social Change 45, no. 2-3 (1978): 201-212

Nováky, Erzsébet and Ádám Schmidt. (eds.) "Technology of Future and Its Social Implications" Based on the Lectures of the European Regional Experts Meeting. Budapest: HAS, Institute for Social Sciences, Theoretical Research Institute of Trade Unions, 1988. 
Nováky, Erzsébet. (ed.) Developing Environmental Strategies Through Futures Research. Budapest: Ministry for Environment and Regional Policy, 1991.

Nováky, Erzsébet. (ed.) Futures Studies. (in Hungarian) Budapest: Aula Kiadó, 1992.

Nováky, Erzsébet, Éva Hideg, and István Kappéter. "Future Orientation in Hungarian Society." Futures 26, no. 7 (1994): 759-770.

Nováky, Erzsébet, Éva Hideg, and Katalin Gáspárné. “Chaotic Behaviour of Economic and Social Macro Indicators in Hungary.” Journal of Futures Studies 1, no. 2 (1997): 11-31.

Nováky, Erzsébet. (ed.) Hungary after tomorrow. (in Hungarian) Budapest: Budapesti Közgazdaságtudományi és Államigazgatási Egyetem, 2001.

Nováky, Erzsébet, Viorica Ramba Varga, and Mária Kalas Köszegi. (eds.) Futures Studies in the European Ex-Socialist Countries. Budapest: Budapest University of Economic Sciences and Public Administration, 2001.

Nováky, Erzsébet. The Future of Kiskunfélegyháza - Participatory Research Approach of the Future. (in Hungarian) Jövőtanulmányok 20. Budapest: Budapesti Közgazdaságtudományi és Államigazgatási Egyetem, 2003.

Nováky, Erzsébet. “Action Oriented Futures Studies in Hungary.” Futures 38, no. 6 (2006): 685-695

Nováky, Erzsébet. (ed.) Hungary 2025. (in Hungarian) Budapest: Gazdasági és Szociális Tanács, 2010.

Nováky, Erzsébet, and Réka Várnagy. "Discovering Our Futures - a Hungarian Example." Futures Special Issue New Generations 45, no. 1 (2013): 45-54.

Nováky, Erzsébet and Orosz, Miklós. "Analysing Hungarian Macro Indicators by the Method of Chaos Theory." Journal of Futures Studies 19, no. 4 (2015): 31-50.

Simai, Mihály. Towards the Third Millennium. (in Hungarian) Budapest: Kossuth Könyvkiadó, 1976.

Simai, Mihály. The Global Economy in Bustle of the XXI Century. (in Hungarian) Budapest: Akadémiai Kiadó, 2007a.

Simai, Mihály. "The World and the EU in the Bumpy Roads of the Century XXI." (in Hungarian) Magyar Tudomány 168, no. 9 (2007b): 1130-1135.

Simai, Mihály. "Spatial Structure and Geo-economics." (in Hungarian) Tér és Társadalom 28, no. 1 (2014): 25-39.

Sipos, Béla. Price Forecasts for Enterprises. (in Hungarian) Budapest: Közgazdasági és Jogi Könyvkiadó, 1985. 
Tóthné, Szita Klára. "Evaluating of Brown Field Area, Revitalisation and Solution by Industrial Ecology.” (in Hungarian) Ipari Ökológia 2, no. 1 (2013): 77-99.

Tóthné, Szita Klára. "Green Growth in the OECD State of the Art." The Theory Methodology and Practice. 10, no. 2 (2014): 59-66. 